\title{
REPENTANCE IN PENANCE PUNISHMENTS
}

\author{
Mohammad Hassan Hajariyan ${ }^{1}$ \\ Siamak Jafarzadeh ${ }^{2}$ \\ Mohammad Hassan Javadi ${ }^{3}$
}

\begin{abstract}
In Islamic sources, including verses of the Quran and traditions, as well as viewpoints of various religions
\end{abstract} such as Christianity and Judaism, repentance has been considered to have a high position, in a way that it has been known as salvation and prosperity of mankind. In accordance with religious sources, Islamic Penal Code of 2013 stated the repentance as one of the rules of public criminal jurisprudence. In this research, through an analytical and descriptive method, from the viewpoint of jurisconsults, this legal factor is discussed as one of the causes of punishment fall. The result shows that Islamic religions all together agree that the repentance leads to otherworldly punishment fall, but there is a controversy over worldly punishment fall by the repentance. According to
Imamiyah jurisprudence, the repentance is removal of criminal liability in the crimes of God's right, and the repentance, before proving the crime, is considered as the cause of punishment fall. They do not consider repentance after proving the crime with evidence as the cause of punishment, and in the case of repentance, after confessing, they believe that the judge is in charge of punishment and pleading for mercy from guardians of affairs. Those who consider the repentance as the cause of penance punishment fall believe that the repentance in the former way will lead to fall of the discretionary (ta'zir). The Repentance is one of the criminal legal principles of Islam, which, in comparison with other penal schools, is intended to reform the offender and in many cases leads to the fall of

\footnotetext{
${ }^{1}$ Ph.D. Student, Department of Islamic Jurisprudence and Law, Urmia University, Urmia, Iran. Email: mohammadhasanhajariyan@gmail.com

${ }^{2}$ Assistant Professor, Faculty of literature and humanities, of Urmia University, Department of Islamic Jurisprudence and Law, Urmia University, Urmia, Iran. Email: s.jafarzadeh@urmia.ac.ir. ${ }^{3}$ Assistant Professor, Faculty of literature and humanities, of Urmia University, Department of Islamic Jurisprudence and Law, Urmia University, Urmia, Iran. Email: mh.javadi@urmia.ac.ir
} 
punishment; it has been less seen to be used for punishment fall of the offenders in judicial courts.

Keywords: repentance, penance, punishment, criminal liability, penal schools.

\section{Introduction}

Submission of the secondary and subordinate role to the criminal laws focuses on the depenalization policy in anti-crime plans that are resulted from doubts about the effectiveness of traditional suppressive methods in order to achieve the objectives of Islamic Penal Code.

Depenalization policy in the Islamic criminal system provides the possibility to rely on principles that are clearly different from difficult suppressive approaches, while refusing to monopolize the fighting crime methods in punishment. The repentance is among the factors that have been predicted in Islamic Penal Code and for depenalization, in the light of cooperation and participation of the offender in the fighting crime process. Undoubtedly, the most effective way to achieve the objectives of Penal Code is
160

through voluntary actions that are carried out by the offender without the feeling pressured from outside, to repair the effects of crime and to change his life and reform himself. The Islamic Penal Code, approved in 2013 has paid attention to total or partial effect of the repentance in fall of criminal reactions, according to jurisprudential sources and religious principles, with a new and relatively unexampled approach. The repentance provides a spectacular opportunity to reform the offender by his voluntary compatibility, which results in the pause in criminal procedure. In a way that, the repentance declaration and its ascertainment, suspend or void persecution, continuance of persecution of the accused, issuance of verdict and the punishment. In Article 114 of Islamic Penal Code, legislative stated the effect of the repentance in various crimes, and in Article 115 explained the verdicts of the repentance in the discretionary, while explaining discretionary crimes according to severity of their punishment, regardless of the classification of this type of crimes into religious discretionary and preventive punishments, this explanation is in a way that due it, the repentance results in punishment fall, and sometimes in some 
way it orders to its effectiveness. This research aimed to state the position of the repentance in penance crimes.

\section{The meaning of the repentance}

Repentance in the word: repentance is from the root of "tob" means referring and returning. As Ibn Manzur meant in Lisān al-'Arab (the tongue of the Arabs): repentance is returning from sin (Ibn Manzur,1982) and (Zobeidi, 2007) and (Ibn Fares, 1978). some added sin in the definition of the repentance, and known it as the reference from sin (Ragheb Isfahani, 1993).

Ragheb Isfahani also says about the meaning of "tob" that: repentance means leaving $\sin$ in the most beautiful way, and it is the most eloquent aspect of the apology, because the apology has three ways, the apologizer denies or accepts what he done and he says that he meant something else (in other words, he tries to justify his work or make excuses for it) or he says that: I have done that (or done that sin) but I did something wrong and I will not repeat and and I will leave it (Ragheb Isfahani, I bid, 1993). The repentance in the Holy Quran comes with two words "to" and "on", which with "to" it means returning to Allah, in fact, it shows the direction of returning and regret of past wrongs to the mankind, such as the verses "... And, $\mathrm{O}$ believers turn to Allah all together, in order that you prosper" (Nuur/31) and "Believers, turn to Allah in sincere repentance" (Tahrim/8). Also, the repentance in the Holy Quran comes with “on" that means acceptance of repentance by Allah (Atef al-Zain, 2001) this kind of repentance is related to Allah, God's repentance means acceptance of repentance from man who has been regretted his dark past and returned from ignorance and deviation, as God says in the following verse: "Allah knows that you have been deceiving yourselves. He has accepted and pardoned you." Therefore, in the Holy Quran, whenever man's repentance is discussed, it means regret of past sins, and wherever God's repentance is discussed, it means the acceptance of repentance and returning to forgiveness and blessing.

Repentance in the term: the terminological concept of repentance is close to its literal meaning. The meaning of repentance in this research is related to the repentance of servants and the acceptance of it by God, in other words it is the terminological meaning of 
repentance, not its literal meaning, for this purpose, there are various definitions for the meaning of repentance: repentance in religion is the abandonment of sin because of its ugliness and regret of what has been happened in the past, deciding to leave that sin and not return to it in future, and also to compensate abandoned acts that can be compensated by returning (Ragheb Isfahani, 1992). Also Motahari stated that repentance is an internal revolution, a kind of uprising from man against himself (Motahari, 1995). According to Ghazali, the repentance is knowledge of the greatness of $\sin$ and regret and the determination to leave it in the present and future, and to compensate for what has been done in the past (Ghazali, 1986). Mulla Ahmad Naraqi said about terminological meaning of repentance: it is return to God by emptying the heart of the intention of sin and getting close to God, which results in abandoning sins and deciding to leave them in future (Naragi, 2004). Nasir al-Din al-Tusi said about terminological meaning of repentance: repentance means returning from sin, and first, should be known that what sin is (Nasir al-Din al-Tusi, 1986). Regarding what has been said so far, it can be said that repentance is to return to God, to regret what has been done, to abandon and not to repeat $\sin$ and to compensate what has been abandoned.

\section{The Meaning and Concept of \\ Punishment}

The literal meaning of punishment: punishment in the word means reward and comeuppance in goodness and badness (Dehkhoda, 1999).

The terminological meaning of punishment: the punishment terminology like repentance closely related to the literal meaning. We state some of learned men's definition regarding punishment here:

According to one of definitions, punishment is a penalty that lawgiver determines it to intimidate and support the society. (Ovis, 2005), according to Dr. Qalechi, punishment is a worldly avenge that applying to the people who committed the unlawful acts and this avenge is obligatory. (Qalechi) Dr. Reza Nour baha explains the punishment as follows: the acts committed by man, if they are contrary to ethics, conscience, justice, law and the reaction against them will be blame, 
criticize, crack down, discipline, and punishment. The use of words in a synonymous and conventional form is acceptable, but when an act contrary to the law should only use the word of punishment, so the punishment is criticizing reward, which created against the act and omission to punish the committer or committers of those acts. (Nourbaha, 2007), other definitions such as: fair punishment against the crime (Bahva, 2007) penalty and punishment that applying to the criminal (Qasemi , 1995), were stated for punishment. With the addition to the above definitions it can be said that, punishment is a penalty, which is applied with the purpose of criminal's intimidation and preventing him from committing crime again and maintaining the security of society based on actual material and corruption.

\section{The Concept and Meaning of Penance}

Literal meaning of penance: penance is the singular form of (Hudod) and in the word means distance, barrier, separator between objects outrace of everything and the prohibition, which also considers the jailer (Hadad) who prevent prisoner from escaping. Compassion is also by this reason called penance, which are preventing their reasons from committing; God limits are also God's forbidden because they are forbidden by the promise of God. " Permitted to you, on the night of the Fast, is the approach to your wives; they are raiment for you, as you are raiment for them. Allah knows that you have been deceiving yourselves. He has accepted and pardoned you. Therefore, you may now touch them and seek what Allah has ordained for you. Eat and drink until the white thread becomes clear to you from a black thread at the dawn. Then resume the fast till nightfall and do not touch them while you cleave to the mosques. These are the Bounds of Allah, do not come near them. As such, He makes known His verses to people so that they will be cautious". Divine laws are also Allah's Hudod, so it is not permissible for man to exceed and it is called Hudod, because it is forbidden to exceed beyond of it (Zahili , 1997).

The terminological meaning of penance: penance in religious terminology is, predestine and determinate punishment, which is decreed in the book or tradition on the body of sinner and criminal in committing some of particular sins, so Imam and ruler don't have right to 
exceed from it. Penance in terminology of Jomhour Gheir $\mathrm{Az}$ Hanafiye is prescribed and specified punishment and compassion, which the type and its extent is determined from the religion and legislator. (MohagheghDamad , 2008) and (Zahili , 1997) but in terminology, Penance of Hanafiye is predestined and obligated punishment that is the Right Of Allah, so it is not called Ta'zir of penance, because it is not predestined. Retaliation is also not called penance although it is predestined but it is the right of people and because of that amnesty and peace is ongoing in it. (Sarakhsi/ Bita/36) (Ibn Abedin , 2000). Also, the penance in Article 15 of the Islamic Penal Code dated 2013/4/21 is also defined as follow: Penances are the punishments that their type, extent and execution quality were determined in religion.

Autopsies of Regret and Remorse in Criminal Schools

Criminal law, like other sciences, owes its advancement and development to the views proposed in its realm. The schools of Penal Code have great contribution in clarifying this science and ultimately legislation of law
164

material, progressive to favor of humanity. In general the proposed schools in masonry sciences contains four main categories, which are these schools respectively described as follows; classical, neoclassical, positivism and Eclectic.

\section{The Classical School}

The mean of classical schools are the views that have been formed in the 18th century. The basis of crime relying on moral responsibility and containing intent or cause of guilt and each person is required to respond the effects and consequences of his criminal act. The school of absolute justice and social benefits are two main schools of classical schools.

\section{School of social welfare}

Jean-Jacques Rousseau, Cesar Beccaria and Jeremy Bentham are some of the scholars of social welfare school. In this school, the basis of criminal liability is violation of social contract, and the purpose of punishment is its social benefit. Considering the equality of all individuals against the law, same punishment must be taken into account 
for everyone while determining punishment and legislating laws, regardless of age, mental and temperamental condition, social status or other conditions; this issue is one of the criticisms of social welfare school, and it is the symbol of undesired explanation of equality principle of individuals against the law. Condemning severe punishment, Montesquieu believed that the cause of occurrence and increase of the crime is the lack of proper punishment. Therefore, if the punishment is fixed and moderate and is finally performed, it will surely be effective in reducing crimes. Because the purpose of punishment is to arouse the conscience of people, create a desire for goodness and to avoid the crime. JeanJacques Rousseau believed that the human being was born free and he is not innately mean and corrupt. By delegating his powers to the community, he had an unwritten contract with community that knew the social responsible for maintaining order and punishing offenders and mutineers.

Barkaria, as the most prominent thinker of the classical school, believes that punishment should be cause to relief of society's individuals and prevent any excitement in feelings of that society.
The punishment should lead to prevent in damaging the society's individual in any way and by any person. Also, in order to achieve the desired goal of punishment, should contains punishments and methods that by observance of proportion, leave most stable and most effective influence on the minds of the people and the least influence of pain on criminal's body. In the end, punishments must remain in the necessity boundary, and if leaves out from this boundary, surely will cause to ruining the public prosperity, which is naturally tyrannical. Therefore, punishment should be carrying out in order to maintaining the public policy. Unlike his predecessors, Bekaria himself considered applying security measures more profitable than punishment and stated it, as a means to prevent wickedness in the future, so that after committing first crime do not commit any other crimes. This issue proves that, the ultimate intent of punishment is to protect the social interests, not to provide moral opinions. It must be acknowledged that, the views expressed in this school are not consistent with reality and in giving authority and will to human involves in excesses. While human is somewhat, subdued by its biological, psychological 
and social conditions. In the approach of this school, punishment is the only way to deal with crime, and fearing from punishment and public intimidation stated as basic factor in deterrence of crimes and brings prospective of this school to the existence arena.

\section{Absolute Justice School}

Absolute Justice School generally denies the punishment's profitseeking purposes. In this approach, the basis for punishment is based on absolute justice, not critical considerations. Therefore, the execution of punishment in any case, even if it does not have benefit, strongly recommended. Kant's ideas in principle, depends only on the ethic philosophy. $\mathrm{He}$ is an intense defender of individual rights. The crime, in his view is a harmful phenomenon and criminal is someone that has undermined moral standards. The purpose of punishment is to return the mental balance of offender. For Kant retaliation is the ultimate limit to the social justice execution. Nevertheless, the only condition that is necessary in this principle is issuance of retaliation award by the law courts and the victim, alone and without a judicial order, allowed executing it. The abandoned island of Kant reminds his abundant emphasis on punishment execution. For example, if an island is destined to be destroyed and islanders would want to leave it, before the leaving island should punish the criminal and then leave the island. Because execution of punishment itself, drawn equal to the realization of justice. In the critique of mentioned school, said that executing absolute punishment is consequent of lot of corruption and violates many of philosophy punishment. This school ignores the independence of criminal law by excessive interference of moral and philosophical rules.

\section{Neoclassic School}

Although the founders of this school thought human, have will and authority and morally responsible but if one suffers from a lack of reason, not insanity, such as neuroses, psychological distress and psychosis should in accordance to mitigating circumstances give him a suitable and light punishment.

\section{Realistic school}


This school, unlike the previous schools is determinism, which introduces criminal's responsibility, social responsibility not moral responsibility and paying great attention to education and preventive actions and the issue of crime social prevention. The reason of crime is combination of external and internal factors. The criminals in realistic school are classifying into five categories of insane criminals, congenital, persistent criminals, accidental and emotional criminal.

\section{Eclecticism school}

This school divided into two schools of Authenticity of Action School and Social defense School.

\section{Pragmatism or Authenticity of Action School}

This school, instead of proposing philosophical issues and subject of algebra and authority seeks to take practical methods for exclusion of criminals. Alike the classic school, which considers criminal's responsibility a moral responsibility and while in the same time believes in the dangerous state of realistic school. In addition to accepting traditional punishments also recognizes educational and preventive actions.

\section{Social Defense School}

In this school, delinquency is a social phenomenon. Crime is not the only way to combat delinquency and should along with providing people's social rights; seek correction and treatment of criminals. Some of social defense schools adherents believe that, social defense rights became replace with the term of criminal law and instead of responsibility concept, the antisociability were used. Unlike the classic school, in determining responsibility extent also takes into account the individual motivation. In general, the social defense school refers to the schools that which, based on anthropological and sociological studies, have adopted a criminal policy to combat delinquency from around the twentieth century.

\section{The Way of Dealing with Criminal}

In the present era, the most common paradigms of justice are 
nemesis justice and restorative justice. The interaction between these two paradigms is the most serious present challenge in criminal justice systems the world. Traditionally, some people search for justice in the concept of remuneration. They thought criminal deserves the punishment according to the severity of the crime. However, the new thoughts of criminal justice seek to find new horizons. The movement of restorative justice began in this regard and gradually expanded by multiple and various processes in the contemporary world. In the nemesis justice, emphasizes on offender's deservedness to the punishment. So should treat him in such a way that he treated to others. In contrast to this pattern, the restorative paradigm emerges as a new paradigm of criminal justice and now known as restorative justice. In this paradigm, instead of relying on the criminal's punishment, paying attention to correcting damages from crime and the needs of victim. The adherents of restorative justice believes that, remuneration pattern of criminal justice in the fight against the crime has failed, and a new model must be proposed to confronting against the crime and prevent it from happening in the future.
These thought are now expanding under the title of "restorative justice".

\section{A. nemesis justice}

The nemesis justice is a model of justice that forms by concentrating on past behavior of criminal and considers him to deserve the punishment. According to this view, the criminal must pay for his misdeeds. This model is a retaliatory, revengefully model and based on reciprocation. Kant's ideas about the paradigm of criminal justice remuneration are the starting point for discuss about justice in the present era. Despite the passage of two centuries, Kant's ideas effects are still seen in criminal rights. Justice is Kant's view is center of gravity for his thoughts. Kant writes: "If justice fails, there will be no value in the world for human life". In particular, in the field of criminal rights the terms of Kant's justice or absolute justice reflects justice as deserving, retaliating and retribution in his thoughts. Alan Neurie believes that, Kantian philosophy is still at the center of criminal justice thought. Hegel is another philosopher whose thoughts are forms basis of punitiveness thoughts, believes that "The concept of 
punishment contains retaliatory considerations (sin ad justice), even if its purpose is to achieve desirable results such as preventing the law defects in future. Hegel considers crime as breach of right that is the kind of wickedness, which should be responded with the same kind of wickedness. Crime is a kind of damage that created by the will of criminal and must be responded by the arrival of damage in the same type. Hegel believes that, if the authority given to victims is subject of "avenge" and if the government, or in other words, the judge and the law became responsible for punishment, is retribution and justice and known the example of revenge as the cases that gives authority to individuals to bring the crime to the court or not. To explain the relationship of revenge and remuneration and critique of Hegel's ideas, that can no longer have a place in the criminal justice system. Because Hegel doesn't have a proper understanding about human originality and lofty place of human. He places his ideas in the service of ordering discipline, which is imposed to the society by the authorities as the law. Consequently, punitiveness is not an ethical theory and ignores human morality. In this thought, punishment is applying just for the reason of violating the law, no one is punished unless he is guilty and guilty is someone who has violated the law.

\section{Criticisms to the Thought of}

\section{Remuneration}

Kant, Hegel, and other philosophers who propagated remuneration thought, do not regard the criminal as worthy to respect. Retaliation, retribution and even brutal vengeance are the criminals act reward. The inhuman and cruel punishments in their view, are justifiable for the criminal that done the bad deeds. This view cause to criminal considers as blameworthy existent. In fact, the element of criminal blaming as one of the main components in nemesis justice rooted in this view. Therefore, in this view because the crime is a bad thing, is bad for committed too and should be blamed. In principle, regardless of this element, punishment will lose its meaning and concept in the perspective of nemesis justice. When the criminal is introduced as a blameworthy agent, its another effect will be maculating his character. This bad tag is also due to this view. The criminal has imposes the pain to victim and society 
and should pay for his crime. In the view of nemesis justice, basically law legislated rational and in terms of morality is justifiable. In this view, the criterion of justice is law. What is the law stipulates is the justice. There are contradictory values in criminal laws. How can these contradictions be solved? Are there ethical principles superior to law? In the political crimes, which is the committing motive is honorable and the legislator has paid attention to the support of such these offenders or in the cases of committing crime because of the need like robbery on poverty what should be done? In other words, in Kant's thoughts is there particular place for motivation or not? In response should be said that, the intention is the main criterion and the motive has no place in nemesis justice.

In the thought of remuneration, the punishment must be proportional to the severity of the crime. While the proportion between the severity of the crime and the punishment is not correct, because this rule means paying attention only to the committed crime, while in a criminal incident, one has to pay attention to several factors and causes, including the status of criminals, victim and society and keep aloof from one-
170 dimensional look. Regarding that, hasn't been acceptable criterion regarding the evaluation of crime severity presented yet and whether or not the victim's situation should be taken into consideration? Is the severity of the damages is on criterion? One of the stated criteria is paying attention to damage. We know that in the intentional and unintentional murder, the type of damage is same why should the punishment be different? On the other hand, at the onset of a crime or a threat to murder, and ..., even though there is no damage, sometimes severe punishments will be legislated. Therefore, in spite of claim of remuneration theory, which is seeks the proportion of crime severity and punishment this is not the case in practice. Therefore, nowadays in the thought of remuneration, relying instead of necessity in proportion of crime severity and punishment rely on sufficiently.

In the thought of punishment remuneration, the role of society and society's impact on occurrence of crime is not taken into account. Nevertheless, merely to explains the concept of crime and then attentions to the reward of this crime. Another cases is that, in this perspective cannot do anything for the 
victim, because in principle criminal's punishment don't have benefit for a victim and it might his loss and damage remains uncompensated. In the nemesis justice, even when the nature of the relationship between criminals and victims recognized in the process of justice, and the goal considered as revive of society's rights and victimized people, cannot lead to social justice because the government practically play role instead of society and victims and considers himself as successor of victim. In the nemesis justice, must concentrate on the past and place what happened in the center of investigation, not what should be done to compensate the damages. Where the nemesis justice considers punishment necessary for reviving the social equality, the restorative justice want to know what is necessary. The center of gravity in restorative justice is reviving the relationship between criminal, victim and society by maintaining the degree of respect, attention and support for them, not only for proving the sin.

\section{B. Restorative justice}

The adherents of restorative justice define crime as an act against the social order, human relationships and human rights violations. On the base of restorative justice model, the crime must be resolved within the realm of the local society where the crime has been committed in that area by the local members of that society, victim and criminal. In this model of justice, the victim has an active role, which gives him the opportunity to deal with criminal and proposing his needs. In this model, the criminal should be helped to can compensate the losses and damages in a desirable way, settle his relationships with victim, and compensate the damages that caused to the social order. Therefore, in this model people are given importance. The criminal, victim and even local members of society became active activist in the realm of justice execution. In order to clarify the concept of restorative justice, the concepts and definitions of restorative justice are first to be investigated. Then, the main elements and its constructive components are explained. The restorative justice emphasizes on importance of improving the role of victims and society members in the passage of their more active involvement in the process of justice and knows the criminals directly responsible for victims 
and societies that have been damaged and loosed. The restorative justice restores the spiritual and material harm of the victims and provides a range of proper opportunities for conversation, negotiation and resolution of the problem whenever possible. These opportunities present greater sense of security and tranquility in society, social coordination, peace and reconciliation for all of those who are involved in the issue. In the nemesis justice, the criminal blaming has a pivotal role while in restorative justice instead of blaming criminal, will pay attention to damages caused from crime. The adherent of restorative justice believes that, this method is better than nemesis justice because it restores the damages done to the victim or at least attempts to restores the victim, the goal of nemesis justice is only to punish the criminal and the victim is ignored.

\section{Elements of Restorative Justice}

Restorative justice seeks to restore the damaged relationships among the crime, the criminal and the community, so elements and parts should be placed next to each other which build a reconstructive model. These elements are in contrast to the elements of punishment justice which emphasize on voluntary and intentional rather than compulsory. In opposition to hostility, concealment, imposed, overt, connive and etc. and the elements of statement of truth, confrontation, mutual agreement, support, in camera and propound that separately are discussed as follows. One of the main elements of the process of restorative justice is needed voluntary for victim and criminal. There should no compulsion, threat or fear. This partnership should not be colorable and formal, as it is observed in the process of the nemesis justice.

In the process of nemesis justice, criminal is not present in the court voluntarily and intentionally, but he/she is forced to and must be tried. Victim also has a colorable and formal role. $\mathrm{He} / \mathrm{she}$ may not have to participate in all cases, but its presence is also artificial and formal. Sometimes his/her position falls as a witness, and he should sit in the row of the audiences and watch a drama whose actors are prosecutor, culprit, attorney, judge and etc. and they have no role in it. So, when a voluntary and intentional attendance is spoken in a process of restorative justice, it means a real and active partnership. In the 
process of nemeses justice, the criminal placed between innocence and fault. The criminal tries to get rid of the punishment by denying and refusing the crime committed. While in restorative justice, the discussion is about accepting sinfulness and expressing regret and remorse and reaccepting again the criminal. It is clear that the precondition for participating in restorative processes is to accept responsibility instead to deny crime. Liyouline and House write in this regard "The first part of the restorative process is to tell the fact,". Another element of a restorative process is the confrontation between the contributors of restorative justice with each other. The victim and criminal narrate the event face to face and with the help and assistance of the mediator, facilitator, family members, legal counselors and etc. They express their opinions and hear the views of the other party. This is named element of encounter or face or meeting. The purpose of this element is to find a way to compensate for and restore the damages. The goal of restorative processes is to restore relationships, and this happens sometime after the end of the encounter between the victim and the criminal. Therefore, the pivotal role of this element becomes clear in completing a restorative process. Because in fact at this stage, we are very close to the goal of restorative justice.

Another key element of the restorative processes is agreement between the victim and criminal on how to compensate for the damage and respond to the crime. In criminal processes, the response to a crime, i.e. punishment is not determined by agreement with the criminal and the victim, the punishment is determined by the criminal laws and by the issuing judge without regard to the will and agreement of the victim and the criminal. However, this punishment may be the case of victim and or even may be the case pleasant for the criminal, as he/she has waited for a heavier punishment. But what it is important that the punishment will not be achieved as a result of an agreement process. But the response to the criminal's action in a restorative process must be achieved through an agreement between the victim and the criminal. The agreement make the restorative process to be known as a compromise process not a imposed compulsory process. In this process the criminal himself/herself may go ahead and declare himself prepared to compensate and conciliate for the 
damages sustained. This is the best condition and the situation which may occur, but in case the first suggestion from the side of the criminal is not presented, again the mediators, facilitators, family members and members of the local community may present suggestions which lead to the agreement made between the victim and the criminal.

Another element of the restorative process is the emphasis on supporting aspects. Supporting the victim, supporting the criminal, supporting vulnerable people such as women, children, sick people and supporting the community. The victim and the criminal may not have equal powers in a process. This imbalance will impede the realization of justice. At first, the idea comes to the mind that the victim needs the support. Of course, this is true in most cases, because he has suffered from the crime. He/she is still at risk of other crime, and he/she must be assured that there will be no victim any more. But the criminal must not be ignored due to the criminal supported and given the authority and necessary power. $\mathrm{He} / \mathrm{she}$ must be supported too in order that balance is made during restorative justice process. He should also be protected to balance and balance in the process of restorative justice. Obviously, a work can not be done to restore and conciliate, in case a balance is not created. As before the restoration, the relationship between the victim and the criminal and the community is the priority of compensating for the victim's losses. Because restorative justice seek to restore: Because restoration of the victim and the criminal and communities. These are observer of supporting aspects in terms of formalities and judgment rule. But the other point to be considered is support for compensating damages sustained, conciliation and shame reaccepted in the criminal. Providing the necessary consultations to the criminal, in cases needed, introducing to a physician and psychologist, finding a suitable job, in case of the criminal unemployed and etc. There are several protections that can be applied to the criminal in a restorative justice process. The criminal may be bespattered or humiliated, especially if he/she is from low and poor people in the society or from ethnic, tribal, religious minorities. In this process, the necessary support will be provided for nondelinquent delinquency. Support In this process, the necessary support will be 
provided for lack of humiliation of the criminal. Protecting the victim also include attempting to compensate for damaged sustained and conciliation, enhancing the sense of security of nonvictimization again. Particularly, these aspects of support about vulnerable people such as women, children, people with disabilities, patients and etc. are very important.

The other one of key elements of restorative processes is inconspicuous and confidential. Originally 14 basic principles have been mentioned: "conversations (discussions) of restorative processes that are not made in the public presence should remain confidential and then there should not be revealed except in cases that the parties have agreed or are required by national law. The importance of this element is that particularly observer of child and adolescents criminal, makes it difficult for them to return to society if it is public. In fact, one of the most important obstacles is in the path of criminal reacceptance, the ruin of prestige, credibility and respect.

In addition, rationally, according to another res integra "No punishment except in accordance with the law", the punishment which is not mentioned in the law, is known as deprecated action. Repenting from these sins is merely the relationship between servant and God, and is the true regret of sin and the decision of avoiding to repeat it. This repentance will also abolish other worldly punishment and if probably Mujtahid (religious ruler) considers punishing him, the worldly punishment abolishes as well. But the role of repentance in the sins which have worldly punishment is in a way that these sins are several types. Some consider the right of God as the right of public and some other consider the right of God as a thing that belongs to the public order and without assigning to an especial person (Jafari Langroudi, 1997) and also some individuals consider that what firstly and by itself is a sin before God and secondly is the breach of human rights, seems to be the God's right. (Marashi, 1983) In the case of public right, there are also disagreements, some consider the public right as the right derived from expediencies or corruptions which is related to individual or individuals (Ibid) and another group states that the public right is the right that reign and guardianship of vindication or remission of it is falsified for righteous 
one and is subject to the demand of people. (Fazel Lankarani, Esteftaat)

\section{The types of sins and crimes and the repentance quality of each one}

Sins have different kinds and the repentance quality is various for each of them. These sins are divided into three categories in a general classification:

a) Sins which do not cause people to lose their rights or lead to penance (hudud) positiveness of God penances: in this case, the $\sin$ is related to the person and dose not spread out. Such as lie, this sin is completely associated to the sinner person, despite the contrition and decision to not repent again and the repentance effects are added to them.

b) Sins which cause fiscal positiveness of public rights or God rights: such as discontinuing the Zakat and Khums; in this case, the repentance is fulfilled when in addition to contrition and remorse from the past, the rights which he is obligated to, be fulfilled.

c) Sins which cause religious penance: this case itself is divided to three items in terms of quality:

- From the aspect of God's right, causes religious penance.

- From the aspect of public right, causes religious penance.

- From the aspect of both God's right and public right causes positiveness of religious penance, such as theft.

\section{Conditions and quality of repentance in God's rights}

To commit some of the crimes such as: adultery (Zina), sodomy and drinking intoxicating drinks (alcohol drinks) are violating the God's rights not public rights; because in adultery and sodomy, the parties do the sin by their consent and willing not by force. In the case of drinking intoxicating drinks, there is only one party involved so it doesn't violate the right of others. Thus it merely violates God's right and the sinner disobeys God, cheapens God's commandments, spreads corruptions which hurt human community and public expediencies. It is certain that everything that hurts to the public expediencies is a violation of God's right and such crimes that are merely related to the God's right 
and the offences that their aspect of God's right overcome such as theft which is punishable; it is probable the crime become evident or remain hidden that the quality of repentant in every case will be considered:

a) Hidden crime: in this case, the repentant is remorse from past and definite decision on avoiding to repeat the sin, it is recommended that the sinner avoid to disclose his sin and introduce himself to the judge (ruler), to confirm this matter, there are several valid narrations in Islamic narrative sources, which two of them are briefly referred here:

Ma'iz Ibn Malik Al Aslami went to see the Prophet (pbuh) and confessed to adultery. Prophet (pbuh) first led him to conceal his sin and tried to make Ma'iz doubtful, but Ma'iz insisted and finally confessed that he committed the adultery. The Prophet said: "it would have been better for you to conceal this sin." (Majlesi, Sonan Beyhaghi, Musnad Ahmad ibn Hanbal, Sunan ibn Majah, 1983) Ali ibn Ebrahim narrates from Ahmad ibn Khalid: "One day a man in Kufa came to Imam Ali
177

(AS) and confessed to adultery and said:

O Amir al-Mu'minin, I committed adultery so purify me. Imam Ali same as the Prophet (pbuh) tried to encourage him to conceal his sin but after the adulterer insisted and confessed four times, the penance verdict has performed on him. Imam stated that: how obscene it is for a man like you to commit such shameful acts and then decry yourself in public. Thus, wasn't it better to repent in your home? I swear to God, undoubtedly, it is better to repent between God and the sinner than I perform the penance verdict on the sinner". (Koleini 1983, Sheikh Hurr Ameli 1993) It should be noted that Imam Ali (AS) expressed four issues in this narrative as well, and thus, he answered the following problems: in this narrative, Imam expressed with grief and anger: "how obscene it is"; so he states the ugliness and inaccuracy of the act of adultery; then, with the word of "selfdisclosure" he notifies about avoiding from decrying, since the disclosure of the sin is worse than the sin itself, this act in addition to disrespect Islam religious commandments, leads to encourage malignant individuals to commit sin; Imam also encourage to repent between servant and God; and at last he stated: 
"repentance is better than performing penance even the penance performed Imam by Imam not by the ruler".

b) Evident crimes: if the crime is revealed, repentance would be the regret of the past, the nonrepetition of crime and adopting the verdict of performing the penance. Needless to say that in this case, the repentance does not prevent the penance; since after decrying the sin, repentance loses its effect to the individual and the community and leads to lack of the worldly legal effect (punishment fall). As Shaykh Tusi wrote in Al-Mabsut: "Whenever the crime is publicly revealed, there is no benefit in abandoning the execution of the penance to the offender". (Shaykh Tusi, 1983)

It is worth noting that the effect of this repentance is for worldly protection of individuals which prevents the penance of them in the other world.

\section{Conditions and quality of repentance in public rights}

Repentance in crimes, such as disregarding public rights, does not lead to punishment fall; because the sinner in addition to ignoring God's commandments, disregarded the rights of community individuals (including financial, physical or spiritual rights) and caused financial, physical or reputational damages and losses for them. These actions and behaviors are forbidden since in addition to oppose the lawgiver, they harm people of the community and their physical, financial and reputational safety is threatened. Anyone who has committed such an act, if he repents, which is, in addition to contrite from doing the sin, decides to avoid the sin forever and performs good deeds; thus certainly he will not be punished in other world and God will accept his repentance by kindness and grace. But he will be punished in this world since worldly punishment is not legislated on the basis of other worldly penance; but the philosophy of these actions, which are crimes, is damaging to individuals' rights, thus the repentance will not prevent the punishment. Therefore, this kind of repentance is not legally effective. The rights that are known to individuals or communities are called public rights which are used along God's 
rights. (Jafari Langroudi, 1997) Also, according to the definition, other crimes that are merely personal and specific individual or individuals are harmed by them, or the like, are related to the pubic rights. (Validi, 1998) These rights are divided into three categories of financial right, physical right and spiritual right.

a) Financial right: some of the crimes in the public rights are the right of property; such as discretionary (Tazir) theft and similar financial crimes. In such cases, the repentance is the regret of the past and deciding not to commit the crime again and returning the stolen property; and if the stolen property has been consumed or wasted, the cost and price of it should be returned to the owner of property and his consent should be obtained.

b) Physical right: in some crimes, through human action, right o on the body is created; such as crimes against the whole of human body or murder that deserve retaliation (Qisas) and intentional battering that leads to the verdict of retaliation. In these cases, the repentance is the regret of the past and deciding not to commit the crime again and accepting the execution of the punishment or paying intended wergild. In this case, the effect of repentance is related to the person's afterlife.

c) Spiritual right: in some of the sins and crimes, the reputation of an individual may be hurt by committing to crime, in this case, the crime has the aspect of public right as well; such as insulting crime (Ghazaf- accusing someone to adultery or sodomy), which leads to threaten an individual's reputation. In this case also repentance is the regret of the past and deciding not to repeat of the crime and adopting the executing of Ghazaf penance; the effect of this type of repentance is also related to the person's afterlife.

\section{The time of repentance}

If the offender, before proving his crime either through confession or testimony of righteous individuals, in front of the religious ruler repents; the famous Imami jurists believe that in this case the punishment will be abolished, 
except in the case of unlawful combatant that in the opinion of these jurists the repentance should be done before arresting the offender not after it. The reason for this is the explicit commandment of Quran. But some of the jurists believe that if the offender, after the repentance, confesses to sin in front of the religious ruler and requests him punishment; then in this case, the penance will execute on him as Ma'iz who asked the Prophet (pbuh) for penancing him and said: "purify me". In the fourth time, the Prophet (pbuh) ordered to stone (Rajm) him. In another case, when a person who committed sodomy and confessed to Ali (AS) four times, the Imam said: I cannot ignore the divine penance.

From the above narrative, this can be comprehended: if a person commit a sin and then confess to the religious ruler, the penance will be executed on him. Now how the theory of "repentance is the cause of punishment fall" can be integrated with the theory of "confession after repentance in front of religious ruler cause to execution of the punishment"? For the integration, if the sinner repents between himself and his God, his repentance will be accepted by God and leads to punishment fall and if
180

after the repentance, he goes to the religious ruler and confess to him and ask for punishment, so the punishment will be executed on him.

From the words of jurists, it is inferred that if the offender repents after attending the court, it will be sufficient and leads to the punishment fall and if he refers to the ruler and confess to him so the punishment will execute on him. The question that arises in this regard is that whether when true repentance is performed, the other worldly penance will vanish and the repentant person will be reformed by the internal revolution and make his decision to never repeat his sin again? Then, how it is possible that after repenting and fall of punishment we say: if he confesses to the ruler, he is punished? This is the violation of the existential philosophy of repentance; then in this case, what is the difference between confession before repentance and confession after repentance or what is the difference between repentant person and unrepentant person? However, if we accept that confession after repentance can lead to punishment then we can say the testimony of witnesses after repentance also can lead to the execution of punishment, and it is exactly moving in the reverse direction 
from repentance condition of the lawgiver. The verses relating to repentance indicate that by repenting the punishment is abolished and what is abandoned cannot recur; hence, acceptance of this theory is doubtful, unless it is based on the verse or narrative.

\section{Repentance after confessing to crime}

If the offender repents after confessing to the crime in front of the religious ruler; the famous opinion of the jurists is that the ruler has the authority to absolve the offender or execute the divine penance on him. However, such repentance does not lead to punishment fall, but only give the religious ruler the authority to absolve the offender.

\section{Repentance after testimony of righteous witnesses}

The famous jurists believe that the crime is proved by the testimony of witnesses, and if the perpetrator repents afterwards, the ruler does not have the authority to absolve him and should execute the divine penance on him.

There are several related narratives to prove this theory, but a few of jurists believe that if the offender repents after proving his crime by the testimony of witnesses, his repent will be accepted by Imam (AS) and can be absolved. Al-Shaykh Al-Mufid in this regard has argued on the "originality of acquittal". According to the acquittal principle, if we doubt the execution of penance on the offender; this offender does not deserve to be punished as the other worldly penance will abolish as well. The opinion of the late Al-Shaykh Al-Mufid is that there is attendance between the punishment fall of this world and that of other world and the one who is not punished in the hereafter will not be punished in the world as well. But his theory is confused; since it seems that ijtihad is against the verses in this theory and does not conform to what is said in the verses and narrations. The late AlShaykh Al-Mufid has given another reason to prove his theory and he referred to Imam Ali (AS), when he absolved the perpetrator after proving his crime by testimony of witnesses. (Sheikh Hurr Ameli, 1983).

Because the delinquent is isolated and this isolation encourages him to do criminal acts. These negative consequences are not limited to the perpetrators and their families will be 
involved. He also finds himself in a disadvantaged position at his place of residence and work. The victim also hurts this, a girl who has been raped by her will not tolerate the trial and will be re-exposed when the trial is announced. His family, too, are openly recidivist. Finally, it is concluded that the advocates of righteous justice continue to insist on the use of punishment and believe that the means of combating crime are to punish the perpetrator. They regard the victim's rights as secondarily important. The advocates of restorative justice believe that punishment can not achieve real justice, that justice is realized when action is taken to correct the damage caused by the crime and compensate for and remedy these injuries, to take action and to identify the material and spiritual needs of the victim and in the direction Fulfilling these needs is an endeavor. Mandatory and unilateral processes of rigorous justice must be transformed into voluntary, conciliatory, and conciliatory processes. The expansion of restorative justice programs in the world reflects the fact that most criminal legal systems have accepted the reconciling paradigm at least alongside justice. In critical crimes, such as violent, terrorist, organized crime, and so on, there is still a need for justice, and regenerative processes in those areas will not be effective and will lead to increased crime in the community. But in simple and insignificant crimes Mostly it is a violation of the rights of individuals. Particularly when the offender is a perpetrator or is at first committing a crime, the use of restorative processes will be beneficial.

\section{Repentance in the Islamic Penal Law}

Repentance is the basis of the Islamic Penal Code (Ardebili, 1992) and in other criminal penal codes of today, there is no example for it. In Islamic criminal law, repentance is considered one of the legal attributes of voiding punishment. In another word, the crime has happened and the perpetrator has the criminal liability. However, observing some expediencies and the application of appropriate factional politics requires that perpetrator's punishment should be voided. For instance, If someone who has been a member of an illegal group, before discovering his team, surrenders himself to legal authorities, or an agent who, in the direction of obedience to his superiors considers the matter legal by mistake, and commits a crime, the 
society will not punish him for various reasons, such as encouraging members of illegal groups to surrender themselves. Thus, as the agent who did the crime is not guilty, he is not punished. The situation for the repentant is the same. In another word, although the committed action is crime and the offender has a criminal liability, the legislator neglects punishing him since he is regretful.

Today, sociologists believe that the perpetrator's punishment is not an absolute goal but it is an instrument for reforming, rehabilitation and intimidating the offender. The penalties should be selected in such a way that it can inform the offender about social regulation. The offender from time to time violates social standards and in fact ignores the social norms so the penalties teach him for a group life, he should observe some regulations and some must and must not. If he is successful, then he will return to the society and start a peaceful life with other people in the community. Now, if we see a perpetrator who, after committing the wrong act, has regretted his deed and is suffering from guilty conscious and is determined not to repeat it, then we punish him, we will do a useless act. The reason is that, in fact, punishment has the negative proposition and we have reached our goal without punishing the offender. The life-giving Islamic School has anticipated such institution in criminal law, and under some conditions such as the criminal's repentance, excludes punishment. This is one of the clear privileges of Islamic penal code. In criminal law, repentance can be defined as returning from sin and criminal acts, regretting for past wrong doing and attempting to do the right thing, and not repeating the crimes. Therefore, there are three elements of regret, apologizing, and not returning to past sins are included in the criminal sense of repentance.

\section{Crime prevention is more important than fighting the crime}

From Islamic perspective, preventing crime is more important than fighting crime. Although repentance results in forgiveness and positiveness of punishment, it is easier to refuse to $\sin$ and not commit crime than to repent. The reason is that human nature gets used to the acts that the person performs and putting aside them is difficult. On the other hand, neglecting and postponing the repentance that is forbidden in narration may cause the offender lose the 
opportunity of repentance. So, the easiest way is to leave the sin and crime. Thus, from the point of view of Islamic criminal law, if the internal evolution happens for the offender and he is reformed, his sentence would be voided, but this legal foundation does not cause people become rebellion since acceptance of repentance has certain conditions, and most importantly, Islam, with its own special arrangement, invites people to abandon guilty and crime, and if they commit sin, they can repent. In this regard, Amir al-Mu'minin Ali (PBUH) says: "leaving the sin is much easier than repent " (Majlesi, 1977).

\section{Repent and its effect on penance}

Repentance has a tangible, distinctive, and significant place in penance. A careful examination and analysis reveal the effectiveness and fatefulness of repentance of an accused person.

Conditions for the repentance in various crimes

Crimes are divided into due to Allah, due men, and the right of the community. In order to realize repentance in each of these divisions, there are conditions that we will discuss in the following section. Sometimes a man commits a sin by his own tongue, such as jealousy and lies. Sometimes sin causes harm to another person or a community, such as combat (moharebeh). Some of the sins have personal punishments that are referred to as penance. There are sins that, as explained in the previous sections, at any time, the type of their punishment depends on the view point of the Islamic ruler. These sins are referred to as discretionary (ta'zir). Some of these discretionaries (ta'zir) are mentioned in the Islamic Penal Code, such as discretionary theft. But for other offenses, like lying, no punishment has been determined. One of the basic principles of criminal law is the legality of punishing the offenses. According to this principle, the act and leaving it are considered as a crime, if they are predicted in law. Furthermore, the punishment that is determined in law can be executed on such crimes. According to the following verses, it can be said that Islamic law also confirms these principles: 
And the two who commit it among you, dishonor them both. But if they repent and correct themselves, leave them alone. Indeed, Allah is ever Accepting of repentance and Merciful (Surah An- Nisa; 16).

And remove the fury in the believers' hearts. And Allah turns in forgiveness to whom $\mathrm{He}$ wills; and Allah is Knowing and Wise (Surah At-Tawbah: 15).

But as for one who had repented, believed, and done righteousness, it is promised by Allah that he will be among the successful (Surah Al-Ghasas: 67).

Furthermore, the well-known Rafi' hadith from the Prophet (pbuh) points to that fact. Given that punishments must be mentioned in the law and people will not be aware of it until they are expressed by the legislator, If the action is intrinsically inappropriate, but the committer is not aware of it and is not mentioned in the

\section{5}

law, he will not be punished or blamed for it.

While the general part of this news can be searched in other narratives that do not permit to forgive unless bringing clear evidence. Among these narratives is the narration from Imam Ali (PBUH) saying: If the evidence is brought, Imam should not accept an excuse. (Ibid). Of course, regarding the repentance of the combatant (the Arabic word is mohareb), the Quran's explicitly says that "Indeed, the penalty for those who wage war against Allah and His Messenger and strive upon earth [to cause] corruption is none but that they be killed or crucified or that their hands and feet be cut off from opposite sides or that they be exiled from the land. That is for them a disgrace in this world; and for them in the Hereafter is a great punishment, Except for those who return [repenting] before you apprehend them. And know that Allah is Forgiving and Merciful. "(Maedeh / 33, 34). He must repent before he is arrested. Not later than that; because the repentance that is carried out after arrest is often not due to fear of God's judgment, but because of the fear of punishment, which is not a real repentance. 
In the case of other crimes, such as adultery or drinking wine (the Arabic work is Khamr), as revealed in verses, the committer can repent before the crime is proved, although he has been arrested as a suspect. It should be noted that repentance before apprehension means that the rebellion is in a situation that cannot escape justice, and not necessarily to be handcuffed or kept in a detention center. For instance, if the security forces find out that the combatant in Iran have established a large organization operating against the system and inform the entire border checkpoints, airports and other relevant authorities about it to prevent them from escaping and it is certain that they will be arrested within the next few days, it seems that their repentance will not be accepted within these days, provided that the members of the organization are aware that their organization has been betrayed. In this case, the repentance is due to the fear of punishment, not the fear of God's judgment. So if the member of the organization repents while is not aware of the betrayal, it seems that his repentance will be accepted. The appearance of the holy verse shows that of the combatant himself is aware that the government will punish him. In this case, the true repentance is questionable.

\section{Repentance in the New Islamic Penal Code}

In the Islamic Penal Code of 1992, repentance had been considered in dispersed and diverse cases, and the rules and regulations governing it were not clear. But in the new Islamic Penal Code, the legislator has collected the laws of repentance and stated them in Section 5 of Chapter 11 of the Act, and under articles 114 to 119 . The sentences mentioned in the fifth section of the eleventh chapter of the new Islamic Penal Code are:

- In offenses reserving penance, except accusing someone to sodomy or adultery or combat (moharebeh), before accusation is proved, the repentance does not void penance.

- In the same crimes, if the accusation is proved with a confession, repentance after proving the crime will cause the court to request the head of the judiciary to obtain the Supreme Leader's pardon for the repentant. 
- The repentance of the combatant (mohareb) before being arrested will void penance.

-In fornication with chastity, reluctance or deceit, accepting the repentance before proving the crime or, if proven by confession, makes it possible for the court to request a pardon for the offender as described above, but at the same time the offender has been sentenced to more than six months' discretionary imprisonment and up to a maximum of 2 years, or a whip of 31 to 99 beats or both. - In grades 6, 7, and 8 of the discretionary (taziri) offenses, with a minimum penalty of 3 months and a maximum of 2 years, acceptance of repentance results in the void of penalty and in other discretionary offenses, it results in the installment of the punishment.

According to what has been said so far, other cases which are debatable about repentance are as follows:

- $\quad$ Repentance is not applicable to those who repeat discretionary offenses. Furthermore, in the cases where there is exemption of the punishment, the replacement of the sentence, suspension or the rebate of the punishment, as well as punishments concerning children and juvenile offenses, the verdicts of repentance are not enforced.

Repent does not result in the void of retaliation (Qisas), wergild (Diyah), penance of accusing someone to sodomy or adultery (Qazf's), and penance of combat (moharebe).

Before the determination of the verdict of his repentance, the accused can submit the related evidence to the prosecutor.

- If the prosecutor opposes the void or the rebate of punishment, he may object to the appeal authority.

\section{A Comparative view to repentance in} the previous and recent Islamic penal code

In the recent Islamic penal code, rebate is considered for punishing the regretful repentors who show the sign of regret and even in some cases, under legal conditions, the perpetrator of the offense is recognized as innocent. In continue, we study this jurisprudential institution in the recent Islamic Penal Code. In the recent Islamic Penal Code, repentance is one of the religious tools of voiding punishment and chapter 11, articles 114 to 119 of the recent Islamic Penal Code discusses about it under the 
title of void of punishment. This indicates that the jurisprudential institution of repentance is important for the law makers. In offenses reserving penance, if repentance takes place before proving the crime, it voids the punishment. It should be mentioned that according to the religion (Shari'a) and the recent Islamic penal code, in some cases, repentance turns the penance punishment into discretionary punishment. Paragraph 2 of article 114 of the recent Islamic penal code says that repentance causes the adulterer and the committer of the sodomy receive the discretionary imprisonment or lashing.

In the recent Islamic penal code, repentance is discussed as one topic which is better than the disparate provisions of various offenses in the 1991 law. In addition, the recent law, in general, points to the role of repentance in the offenses reserving penance.

Accordingly, in some cases, the repentance of the offender voids the punishment and in some other cases, it gives the court the authority to rebate the punishment of the penance offender. This fact i.e. the generalization of the effect of repentance on penance crimes is one of the innovations of the recent law. Another significant point in the recent law is that if the crime is repeated, repentance will not void the punishment since the repetition of the offense is contrary to the nature of repentance (feeling regret about the criminal actions and trying to compensate them). In fact, the repentance of a person who confesses his criminal activity before he is arrested is accepted. In fact, he is protected from any violation.

Repentance can be effective in all kinds of major and minor crimes, but recognizing the situation in which the repentance is accepted lays in the judge's authority. In another word, when the perpetrator declares himself as a repentant person, recognition of the acceptance of repentance and the rebate of punishment is the task of a judge. If a person repents and cooperates to void the consequences of his crime, he can enjoy the legal and judicial discounts predicted in the recent law. A repentant of committing a criminal act can, in some cases, take advantage of the suspension of punishment. In some of the materials in the new law, the repentance of the offender provides him with the possibility that, upon the request of the judge, he will be subject to the Leader's amnesty. The offender's repentance after committing a crime can have many 
benefits to him. For example, whenever someone confesses to the adultery which deserves penance and then repents, the judge can request the Leader's pardon for him or penance him. In other crimes such as drinking alcohol and sodomy, repentance is also anticipated. Therefore, by examining these cases, we find that in Iranian new Islamic penal code, the legislator has a higher look upon this jurisprudential institution and has discussed about it in the best way.

\section{Conclusion}

From the above mentioned facts, it is concluded that repentance is one of the best ways to prevent crime and to correct the perpetrators' behavior. So, the legislator should study this issue (voiding due to repentance) which is discussed in statuses. In legal texts, the legislator should also predict the related areas of the repentance. If the life-giving principles of the Islamic law are regularly written, the base of salvation and guidance of the society will be provided, but if it is imperfectly foreseen in the laws, it will invade the genuine Islamic principles by the ignorant and dissident. So it is necessary that the law makers pay attention to this important issue when designing Islamic law. Besides, given the legal effects of repentance on Iranian judges, it is assumed that they will pay more attention to this when hearing and settling the dispute and executing the verdicts. Considering the verses of Quran and traditions related to repentance, it is inferred that repentance is just the true regret and the determination to leave sin and to repent there is no need to say a particular word or do a certain act. It is worth noting that no matter how much security and training actions are done for criminals, repentance voids punishment. Punishing the perpetrator has several purposes such as intimidation, threatening, and reforming the perpetrator, and denying his wrong doing. Islam jurisprudence focuses on the educational purpose of punishment which has an effective role in reforming the perpetrator and bringing him to a decent and prosperous position. This purpose is a kind of reverence for the offender. all the Islamic religions believe that repentance prevents the punishment in the other world. However, these religions have different ideas about the role of repentance in the void of criminal punishment in this world. Famous Imams' jurists, some 
scholars of Shafi'i and Maliki and Hanabalah jurists believe that repentance would only cause the void of combat (moharebe) punishment. Ibn Abbas, Mujahid, Qanadah and Ibn Hazm, believe that repentance does not play a role in the void of punishment in this world. Abu Hanifa, Malik and Shafi'i believe that repentance only voids the punishment for combat (moharebeh) and does not affect the punishment for other crimes. The idea of those who believe in the void of the penance through repentance seems to be more correct since repentance is an internal relation between God and the guilty person. Many Quranic verses express the penalty for each type of crime which are followed by verses which show repentance is accepted by God. This shows that repentance, as a reliable factor, voids the punishment in this world. Before arresting the criminal, repentance voids penalty. After arresting, if the offender confesses and the crime is proved, the judge can request the Leader to pardon the criminal. So, it is necessary that in judiciary courts, the repentance is paid more attention. An institution consisting of experts and the judge's advisers is needed to affect the judge's decision on issuing the verdict.
The people of the society should consider social position for the repentant person equal to other people, and even encourages him as he reforms himself. This behavior should turn to be part of the culture of a society. It is better that the committed ethical scholars and lawyers a little more discuss about the moral aspects of criminal law so that they can explain the accusation and doubts from the very moral aspect of criminal law and by explaining the legal issues of ethics ensure Muslims that in the light of the Islamic criminal law, their prosperity and personal and social security are guaranteed.

\section{References}

The Holy Qur'an, the handscript of Ahmad Nayrizi, translated by Mahdi Elahi Ghomshe'ie, Qom, Daraltfsir Publications, Ismailian Printing House, VOL 2, 1998.

Ibn Faris, Abolhossein, Mo'jam Maghayis al-Loghahe, Research: Abdolsalam Mohammad Haroun, Qom, Publisher: Islamic Maktab al-A'lam, 1984. 
Ibn Manzour Al-Arifiqi, Jamal al-Din,

Muhammad Ibn Mokram, Lassan al-

Arab, Beirut, Publisher: Darahia al-

Tharath al-Arabi, $1^{\text {st }}$ Edition, 1408 AH. 1988 AD.

Al Ansari, Al-Sheikh Morteza, Book of Al-Makaseb, Tabriz, $2^{\text {nd }}$ Edition, 1997.

Ardebili, Mohammad Ibn Hossein, The Treatise of Bekaria, and the issue of crimes and punishments, p. 71, Tehran University Press, 2001.

Jafari Langroudi, Mohammad Jafar, Thermionology of Law, No. 1821, p. 224, Tehran, SAMT Publication, 2005.

Al-Hur al ameli, Al-Sheikh Mohammed ibn al-Hassan, Wassail al-Shi'a ela-tahsil masa'el al-Sharia (30 volumes), Qom, Research and publication: Al-Ali beit institute: Le-ehya al-Torath, $2^{\text {nd }}$ Edition, 1993.

Al-Ragheb al-Esfahani, Abolqasem, Hossein ibn Muhammad, Al-mofradat fi Gharib al-Quran, Iran, Publisher: Nasre-Kabul Office, $2^{\text {nd }}$ Edition, 1984.

Zera'at, Abbas, Islamic Penal Code in Current Order of Law, Mizan Publication, $1^{\text {st }}$ Edition, Winter 2001.
Sarkhosh, Jawad, Principles of Legal Fiqh thought or research explanation of the Principles of Mozaffar jurisprudence, Tehran, Behnami Publication, $1^{\text {st }}$ Edition, 2004.

Al-Shahid al-Awwal, Shams al-Din, Mohammad Ibin Maki al-Ameli, AlDorus al-Sharia fi Fiqh al-Imamiyah, Qom, Publisher: Al-Nashr al-Islami institute, 1412.

Al-Shihid al-Thani, al-Jubayi al-Ameli, Zein al-Din, al-Rawzah al-bahieh fi sharh al-loma'a al-Da meshqiyah lel shahid al-Awwal, Qom, Publisher: Dar altafsir esma'ilian, $1^{\text {st }}$ Edition, 2002.

Shiri, Abbas, Void of punishment in Islamic Criminal Law of Iran, Tehran, Academic Jihad of Shahid Beheshti Publishing House, 1993.

Al-Sadough, Abu Ja'far, Muhammad Ibin Ali ibn al-Hussein, known as Ibn Babawayh, Manlayahzarah al-Faghih, Tehran, Publisher: Dar al-Kotob alIslamieh, $5^{\text {th }}$ Edition, 2011. 
Sanei, Parviz, General Penal Law, $2^{\text {nd }}$ Edition, p. 312, Tehran, Mizan publication, 2006.

Al-Tabatabayi Al-Hakim, Al-Sayed Mohsen, Mostamsek Al-Orvah AlWosqa, Najaf, Publisher: Al-Najaf publication, $2^{\text {nd }}$ Edition, 1998.

Ameli, Baha'addin, Mohammed ibn Husayn, known as Sheikh Baha'i, Jame Abbasi, Tehran, Publisher: Farahani Publishing Institute, Bita.

Odeh, Abdul Qadir, Al-tashri Al-Jenai, Lebanon, Beirut, Dar Elktb al-Arabi, Bethlehem.

Al-Allame al Tabataba'i, al-Sayyed Mohammad Hussein, Al-Mizan fi Tafsir al-Quran, Tehran, Publisher: Dar alKetab al-Islamiyah, $1^{\text {st }}$ Edition, 1998.

Almjlesi, Mohammad Baqir, Baharalanvar, Al-jameeh Le dorar akhbar aemmeh al-athar, Tehran, Publisher: Al-Maktabeh-al-Islamiyya, $2^{\text {nd }}$ Edition, 2019.

Al-Muhaqeq Al-Helli, Abulqasem, Najm al-Din, Sharaye' al-Islam fi masa'el al-Hilal and Al-Haram, Research: Abdul Hussein Mohammad
192

Ali, Beirut, Publisher: Dar al-azwa', $2^{\text {nd }}$

Edition, 1403 AH. 1983 AD.

Al Meshkini, Almirza Ali, Al-Fiqh AlMa'thureh, Qom, Publisher: Nashr alHadi Office, $2^{\text {nd }}$ Edition, 1997.

Al-Mozaffar, Mohammad Reza, Osul al-Feqh, Research by Ali Shirvani, Qom, Publisher: Dar al-elm Publication Institute, $1^{\text {st }}$ Edition, 2000.

Al-Mufid, Abu Abdullah, Mohammed ibn Muhammad al-Numan, known as Sheikh Mufid, Al-Maqnaha, Qom, Publisher: Al-Nashr Al-Islami Institute, $2^{\text {nd }}$ Edition, 1990.

Al-Musawi al-Ardebili, Al-Sayyed Abdul-Karim, Fiqh al-Hodood va alTazirat, Qom, Publisher: Maktabeh alAmir Al-Mu'minin 7, $1^{\text {st }}$ Edition,1992.

Mousavi Bojnourdi, Seyyed Mohammad, The Rules of Feghhia, Tehran, Publisher: Orouj Publishing Institute, $3^{\text {rd }}$ Edition, 2000.

Mohammadi, Abolhassan, The rules of jurisprudence, Tehran, Publisher: Yalda Publishing House, $2^{\text {nd }}$ Edition, 1996. 
Mohammadi Gilani, Mohammad,

Criminal Law in Islam, Introduction and

Footnote by Hossein Ansarian,

Publisher: Al-Mahdi Publishing House, $2^{\text {nd }}$ Edition, 1984.

Mirzaye Qomi, Abulqasem ibn alHassan, Jame' Al-shetat, Corrected by Morteza Razavi, Tehran, Publisher: Keyhan Publishing Co., $1^{\text {st }}$ Edition, 1997.

Al-Najafi, Al-Sheikh Mohammad Hassan, Javaher al-kalam fi sharh Sharayeh al-Islam lel mohagheq al-Helli, Tehran, Publisher: Dar al-Kotob alIslamiyah, $6^{\text {th }}$ Edition, 2016.

Noor Baha, Reza, Public Criminal Law, Fifth Edition, Ganj Danesh Library, Dad Afarin Publishing House, 2001.

Alizdi, Al-Seyyed Mohammad Kazem al Tabataba'ie, Al-orvah al-Wosgha, Tehran, Publisher Dar alketab alIslamiyah, $2^{\text {nd }}$ Edition, 2009

Validi, Mohammad Saleh, General Criminal Law, $4^{\text {th }}$ Edition, p. 244, Tehran, SAMT publication, 2008.

Hashemi, Seyyed Hassan, Disbelief and freedom, Tehran, Publisher: Publishing
Organization of the Islamic Culture and Thought Organization, $2^{\text {nd }}$ Edition, 2007.

Hashemi Shahroudi, Seyyed Mahmoud, The requirements of Criminal jurisdiction, Tehran, Dadgostar Publishing, 1998.

Zahar Howard, A book on restorative justice, translated by Dr. Hossein Gholami, First edition, Majd Publications, Tehran, 2004.

Shiri Abbas: "Restorative Justice, Foundations and Activists", Ph.D. thesis in Criminal Law and Criminology, guided by Alli Hossein Najafi Ebandabadi, Faculty of Law, Shahid Beheshti University, Academic Year 2006-2007.

Kant, Emanuel, Philosophy of Law, Translation by Dr. Manouchehr Sanei, Dare Bidi, Naghsh va Negar Publications, First Edition, Tehran, 2001 .

Najafi Abrandabadi, Ali Hossein: "From" Classic Criminal Justice toRestorative Justice", Specialized Magazine of Razavi Islamic University, 
Theology and Law, Third Year, Nos 9 and 10, Autumn and Winter 2003.

Hegel, George, and Wilhelm Friedrich, elements of the philosophy of law, or a summary of natural law and political science, along with the full text, Edward Ganes' attachment, based on the notes of HG Hoteau and Kung Fön griesheim, translated by Mahbod Irani, First edition, Parvin Publishing House, Tehran, 1999. 